DOI: $10.7242 / 2658-705 X / 2019.3 .9$

УДК 579.66

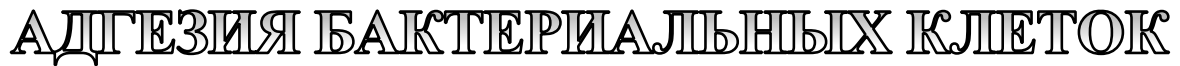

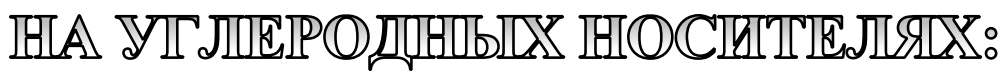

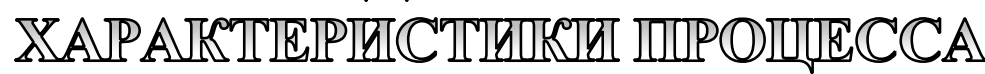

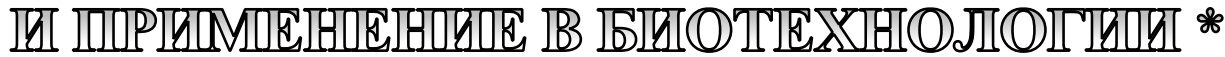

Ю.Г. Максимова, Институт экологии и генетики микроорганизмов УрО РАН

А.Ю. Максимов, Институт экологии и генетики микроорганизмов УрО РАН

В.А. Демаков, Институт экологии и генетики микроорганизмов УрО РАН

В статье дан краткий обзор методов изучения процесса адгезии бактериальных клеток на нерастворимых носителях абиотической природы (углеродных материалах). Определение гидрофообности микробных клеток и носителя, дисперсности, шероховатости поверхности носителя позволяет выявить основные закономерности адгезии бактерий на углеродных адсорбентах. Показано, что адгезированная биомасса на гидрофобном носителе тем больше, чем выше гидрофобность поверхности клеток. Корреляционный анализ показал отсутствие достоверной связи между шероховатостью поверхности, гидрофробностью и дисперсностью носителей, с одной стороны, и массой адгезированных клеток, с другой стороны, при рассмотрении этих характеристик по отдельности, что говорит о необходимости комплексного подхода к оценке носителя для иммобилизации микробных клеток. Масса (количество) адсорбированных клеток зависит от их концентрации в суспензии. При этом характер адсорбции, сменяемой впоследствии адгезией, может описываться либо теорией полимолекулярной адсорбции Брунауэра, Эммета, Теллера, что предполагает фрормирование полислоя клеток на поверхности, либо в случае насыщения носителя клетками графики имеют вид изотерм Лэнгмюра. Элементный состав носителя оказывает определенное воздействие на фризиологическое состояние адгезированных клеток, поэтому он должен быть учтен при выборе оптимального носителя для клеток в гетерогенном биокатализе. Сканирующая электронная микроскопия позволяет визуализировать адгезированные клетки. Адгезированные клетки нитрилгидролизующих бактерий могут быть использованы в качестве биокатализаторов процесса фрерментативной трансформации нитрилов и амидов или в процессах очистки сред от этих токсичных веществ.

Ключевые слова: адгезия бактерий, биопленки, углеродные материаль, иммобилизачия клеток микроорганизмов, гидрофобность, профилометрия, сканирующая электронная микроскопия, рентгеновский энергодисперсионный микроанализ.

\footnotetext{
* Работа выполнена в рамках государственного задания, номер госрегистрации темы № 01201353249 «Молекулярные механизмы адаптации микроорганизмов к факторам среды».
} 
Адгезия клеток бактерий к поверхности является начальным этапом формирования биопленок. Согласно представлениям современной микробиологии, микроорганизмы существуют в окружающей среде в виде прикрепленных к поверхности многовидовых колоний, погруженных в общий полимерный матрикс, выделяемый клетками $[5,6]$. В биотехнологии активно используется эта способность живых организмов микронных размеров формировать такие структуры: так, очистка сточных вод осуществляется микробными сообществами, образующими флокулы, гранулы и биопленки [7]; в процессах биокатализа, при получении полезных продуктов путем ферментативной трансформации или в процессе ферментации (например, в процессе получения спирта, ферментов, органических кислот) также могут функционировать биопленки бактерий или дрожжей $[8,9,11]$. Процесс биопленкообразования во многом зависит от способности микроорганизмов прикрепляться к поверхности, и первый этап формирования биопленки адгезия клеток на нерастворимом субстрате - является определяющим в образовании массивной биопленки.

Углеродные материалы могут с успехом применяться как носители для адгезии бактериальных клеток в биотехнологических процессах, в основном благодаря биосовместимости, инертности, биологической и химической стойкости, возможности получения в виде различных технологических форм (порошка, гранул, волокон). Так, для биокаталитического процесса получения амидов из нитрилов карбоновых кислот нами были использованы биокатализаторы на основе бактериальных клеток, обладающих нитрилгидролизующей активностью, которые были адгезированы на углеродных материалах.

Адгезия бактериальных клеток на нерастворимых носителях является результатом взаимодействия двух факторов свойств клеточной поверхности и характеристик самого материала, на котором закрепляются клетки. Следовательно, для изучения этого процесса необходимо опре- деление таких свойств носителей и поверхности клеток, как гидрофобность, шероховатость и элементный состав материала.

Далее будут рассмотрены основные характеристики абиотических носителей и поверхности бактериальных клеток, влияющие на процесс адгезии.

\section{Влияние гидрофобности поверхности микробных клеток на их адгезию на углеродных материалах}

Гидрофобность углеродсодержащих носителей оценивали по адсорбции нафталина из 0,1 мМ водного раствора [10], гидрофобность поверхности клеток - по относительному распределению клеток между фазами вода/гексадекан [12]. Изучали адгезию клеток 4 штаммов бактерий, различающихся гидрофобностью поверхности: грамотрицательных Pseudomonas fluorescens C2, Acinetobacter guillouiae 11h, Alcaligenes faecalis 2 и грамположительных Rhodococcus erythropolis 11-2 и Rh. ruber gt1. Клетки адгезировали на углеродных адсорбентах марок БАУ и Norit PK1-3 (дробленые активные угли производства Россия и Голландия соответственно), СУМС, Сибунит и «Сапропель» (углеродные адсорбенты, предоставленные сотрудниками института катализа имени Г.К. Борескова РАН, г. Новосибирск), гранулированные активные угли ФТД и ФАС (производства Россия). Технологические характеристики носителей представлены в статьях [1-3].

Клеточная стенка родококков была наиболее гидрофобной: 40-50\% клеток из смеси гексадекан/вода переходило в фазу гексадекана. Поверхность клеток псевдомонад и ацинетобактерий была гидрофильной, не более 5-6\% клеток адсорбировалось к гексадекану. Клетки алкалигенесов были слабо гидрофобны - этот показатель составлял 18,5\%. Гидрофобность носителей варьировалась в диапазоне от 20 до 90\%.

Определяли массу адгезированных клеток бактерий, различающихся гидрофобностью клеточной стенки, на носителях с различной гидрофобностью поверхности (табл. 1). 
Таблищча 1

Масса адгезированных клеток бактерий, различающихся по гидрофобности поверхности, на углеродных носителях

\begin{tabular}{|c|c|c|c|c|c|c|}
\hline \multicolumn{2}{|c|}{ Штаммы } & $\begin{array}{c}P s . \\
\text { fluorescens C2 }\end{array}$ & $\begin{array}{c}\text { Ac. } \\
\text { guillouiae } \\
\end{array}$ & Al. faecalis 2 & $\begin{array}{c}R h . \\
\text { erythropolis }\end{array}$ & $\begin{array}{c}\text { Rh. ruber } \\
\text { gt1 }\end{array}$ \\
\hline \multicolumn{2}{|c|}{ гидрофобоность клеток, \% } & $5,9 \pm 1,8$ & $4,8 \pm 2,3$ & $18,5 \pm 4,5$ & $41,1 \pm 8,2$ & $52,5 \pm 2,0$ \\
\hline носители & $\begin{array}{c}\text { гидро- } \\
\text { фобность } \\
\text { носителей, } \\
\%\end{array}$ & \multicolumn{5}{|c|}{ Масса адгезированных клеток, мг/г } \\
\hline БАУ & $65,9 \pm 4,5$ & $1,7 \pm 0,3$ & $2,3 \pm 0,5$ & $3,9 \pm 0,9$ & $7,9 \pm 0,5$ & $14,5 \pm 0,0$ \\
\hline Norit PK1-3 & $91,9 \pm 6,0$ & $3,3 \pm 0,4$ & $0,1 \pm 0,0$ & $2,9 \pm 0,6$ & $14,5 \pm 0,8$ & $13,0 \pm 0,0$ \\
\hline ФТД & $60,4 \pm 4,4$ & $0,03 \pm 0,02$ & $3,5 \pm 0,3$ & $3,5 \pm 0,1$ & $8,1 \pm 1,1$ & $12,0 \pm 0,0$ \\
\hline ФAC & $54,6 \pm 8,9$ & $1,6 \pm 0,3$ & $0,6 \pm 0,1$ & $2,4 \pm 0,8$ & $13,0 \pm 0,4$ & $8,0 \pm 0,0$ \\
\hline CУMC & $36,5 \pm 6,2$ & $4,8 \pm 0,2$ & $1,1 \pm 0,3$ & $3,7 \pm 0,3$ & $15,2 \pm 0,8$ & $7,0 \pm 0,0$ \\
\hline Сибунит & $46,0 \pm 2,2$ & $9,3 \pm 0,8$ & $6,0 \pm 0,3$ & $13,0 \pm 0,5$ & $36,6 \pm 0,4$ & $9,5 \pm 0,0$ \\
\hline Сапропель & $20,8 \pm 1,0$ & $11,6 \pm 0,1$ & $9,7 \pm 0,0$ & $15,2 \pm 0,8$ & $37,3 \pm 0,6$ & $13,0 \pm 0,0$ \\
\hline
\end{tabular}

Примечание: концентрация исходной клеточной суспензии 1 мг/мл.

Так, для штамма Pseudomonas fluorescens $\mathrm{C} 2$, поверхность клеток которого была оценена как гидрофильная, отмечали умеренную отрицательную связь между массой адгезированных клеток и гидрофобностью носителей $(\mathrm{r}=-0,664 ; \mathrm{p}=0,05)$, что может быть объяснено тем, что все носители в той или иной мере были гидрофобны (от 20 до 92\%). В то же время для других штаммов распределение признаков было отличным от нормального, а корреляция недостоверной. Это может быть связано с тем, что на адгезию влияют и другие свойства носителей, а именно дисперсность, удельная поверхность и размер макропор. Однако при оценке зависимости массы адгезированных клеток изученных штаммов, отличающихся гидрофобностью поверхности, на каждом из изученных углеродсодержащих носителей, была выявлена сильная положительная связь от $\mathrm{r}=0,884$ до $\mathrm{r}=0,950(\mathrm{p}=0,05)$. Это может свидетельствовать о том, что при адгезии на гидрофобном носителе масса прикрепившихся клеток тем выше, чем больше гидрофобность их поверхности.

\section{Влияние дисперсности носителей на адгезию микробных клеток}

На адгезию микробных клеток влияет площадь доступной поверхности материа- ла носителя, которая слагается из внешней и внутренней поверхности макропор, превышающих по своему диаметру размер микробной клетки. Дисперсность носителей (табл. 2) оценивали в световом микроскопе Биомед-6 (Россия) при увеличении 40 раз, результаты обрабатывали в программе Thixomet Lite. В случаe, если раз-

Таблица 2.

Дисперсность носителей

\begin{tabular}{|l|c|c|}
\hline \multicolumn{1}{|c|}{ Носитель } & $\begin{array}{c}\text { Размер } \\
\text { частицы, } \\
\text { мм }\end{array}$ & $\begin{array}{c}\text { Площадь } \\
\text { поверхности } \\
\text { частицы, мм }{ }^{2}\end{array}$ \\
\hline ФТД & $0,392 \pm 0,037$ & $0,137 \pm 0,023$ \\
\hline $\begin{array}{l}\text { ФАС мелкие } \\
\text { частицы }\end{array}$ & $0,995 \pm 0,150$ & $1,270 \pm 0,368$ \\
\hline $\begin{array}{l}\text { ФАС крупные } \\
\text { частицы }\end{array}$ & $2,92 \pm 0,30$ & - \\
\hline $\begin{array}{l}\text { Сырец } \\
\text { порошкообразный }\end{array}$ & $0,021 \pm 0,004$ & $0,00026 \pm 0,00007$ \\
\hline Сырец дробленый & $3,50 \pm 0,56$ & - \\
\hline «Сапропель» & $1,341 \pm 0,125$ & $2,023 \pm 0,345$ \\
\hline Сибунит & $2,69 \pm 0,20$ & - \\
\hline СУМС & $0,925 \pm 0,097$ & $0,958 \pm 0,220$ \\
\hline КВУ массивный & $1,153 \pm 0,202$ & $1,334 \pm 0,453$ \\
\hline $\begin{array}{l}\text { Керамзит / КВУ } \\
\text { слой (6\%) }\end{array}$ & $0,824 \pm 0,116$ & $0,781 \pm 0,182$ \\
\hline $\begin{array}{l}\text { Керамзит / } \\
\text { графитоподобный } \\
\text { слой }\end{array}$ & $7,09 \pm 0,61$ & \\
\hline КВУ/пеностекло & $6,17 \pm 0,74$ & - \\
\hline БАУ & $3,90 \pm 0,55$ & - \\
\hline Когін РК 1-3 & $3,59 \pm 0,49$ & - \\
\hline Шунгит & $3,19 \pm 0,54$ & - \\
\hline
\end{tabular}


мер частиц превышал 1,5 мм, дисперсность оценивали с использованием стереомикроскопа SKT-3BT (Meiji techno, Япония) при увеличении 20 раз.

Корреляционный анализ $(n=14)$ выявил слабую положительную связь между массой адгезированных микробных клеток и дисперсностью носителей $(r=0,220 ; p=0,05)$, что говорит о том, что эта характеристика не является определяющей для адгезии клеток. Только при сравнении носителей одной марки, но разной дисперсности (порошкообразный и дробленый уголь сырец) можно говорить о том, что к материалу с более высокой дисперсностью прикрепляется больше клеток (в среднем 12,5 и 7,38 мг сухих клеток / г носителя соответственно).

\section{Влияние шероховатости поверхности носителей}

на адгезию микробных клеток

Шероховатость поверхности носителей (рис. 1) оценивали на бесконтактном оптическом трехмерном интерферометре-про-
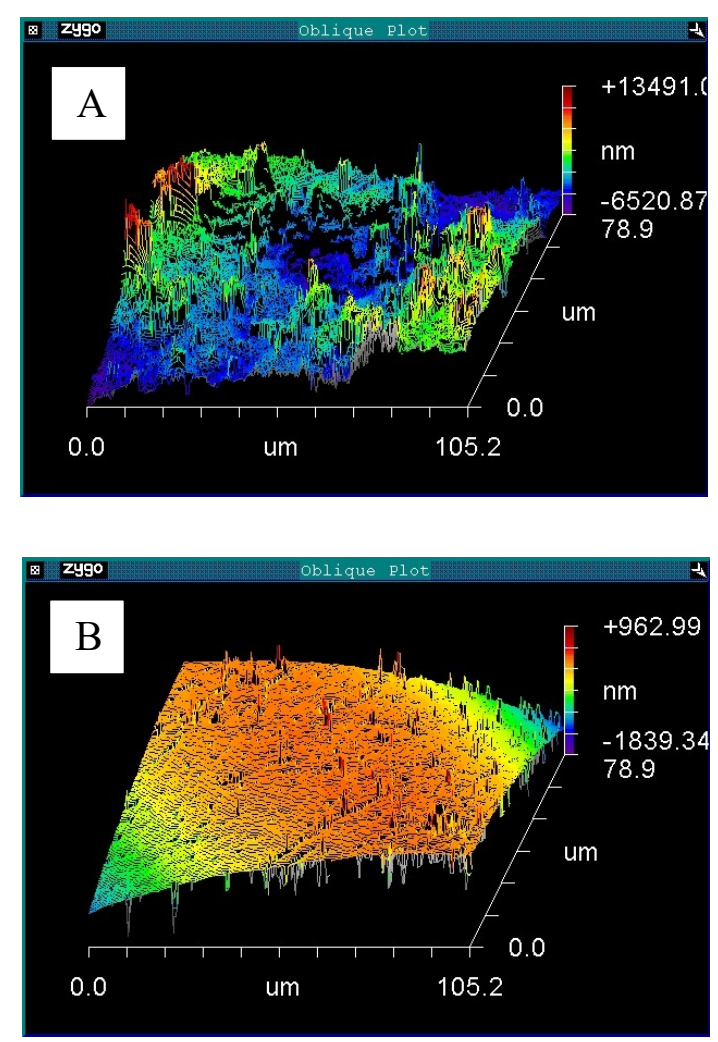

филометре New-View 5000. Определяли шероховатость $\left(\mathrm{R}_{\mathrm{a}}\right)$ и среднее квадратичное отклонение (rms). Оценивали корреляцию массы адгезированных клеток $R$. ruber gt 1 и шероховатости поверхности углеродсодержащих носителей. Был рассчитан непараметрический коэффициент ранговой корреляции Спирмена: $R=-0,276, p=0,47$. Полученные данные указывают на недостоверность этой связи. Вероятно, отсутствие достоверной связи этих параметров является следствием влияния на адгезию бактериальных клеток множества факторов, среди которых изменение шероховатости поверхности адсорбента в изученных пределах не является определяющим.

\section{Элементный состав носителей и его влияние на ферментативную активность адгезированных клеток}

Элементный состав двух отличающихся по происхождению носителей - карбонизированной ткани Урал ТМ-4 (исходное сырье - вискозное волокно) и «Сапропеля» активированного (исходное сырье -
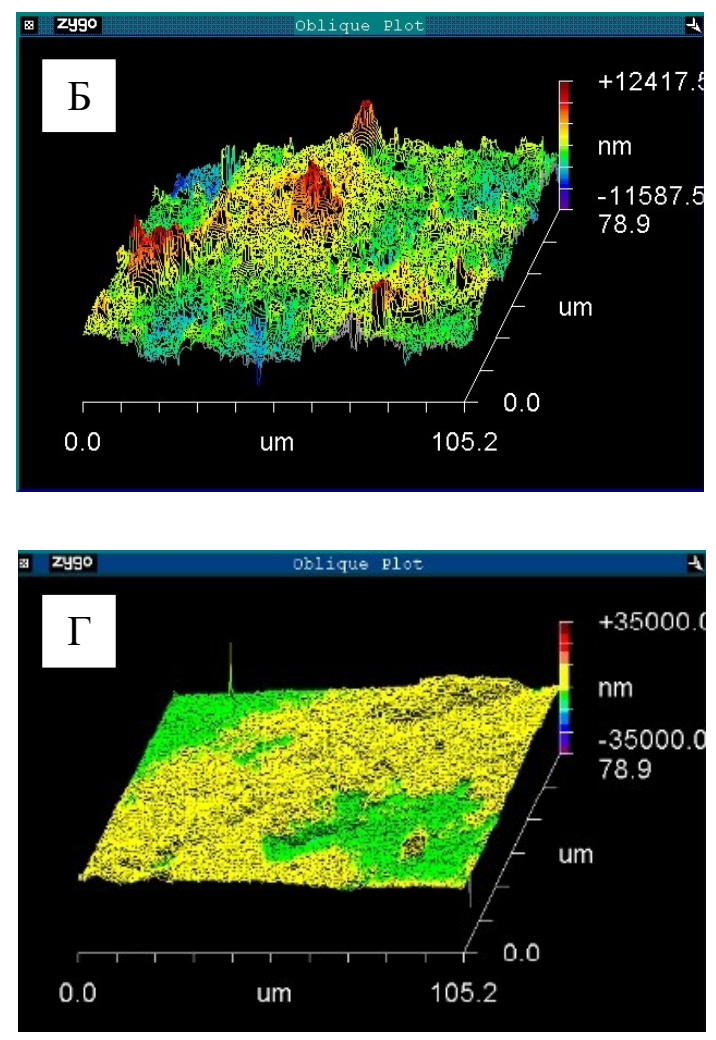

Рис. 1. Шероховатость поверхности носителей: Керамзита со слоем графитоподобного углерода $\left(R_{a}=1034\right.$ мкм, rms $=2212$ мкм $)\left(\right.$ A); Шунгита $\left(R_{a}=1902\right.$ мкм, rms $=2437$ мкм $)$ (Б), $\Phi A C\left(R_{a}=145\right.$ мкм, rms $=110$ мкм $)(B) ;$ Сибунита $\left(R_{a}=727 . м \kappa м, r m s=920 м \kappa м\right)(\Gamma)$ 
ил пресных озер Омской области) был изучен в сканирующем электронном микроскопе MIRA 3 («TESCAN», Чехия) с помощью системы рентгеновского энергодисперсионного микроанализа. Показано, что основным элементом карбонизированной ткани Урал ТМ-4 является углерод (рис. 2, А), тогда как «Сапропель» более сложен по элементному составу, и содержит $\mathrm{Si}, \mathrm{O}, \mathrm{K}, \mathrm{Na}, \mathrm{Mg}, \mathrm{Al}, \mathrm{Ca}, \mathrm{S}, \mathrm{Fe}$ и другие элементы, что может быть объяснено органической природой этого носителя (рис. 2, Б). Можно выдвинуть предположение, что элементный состав носителя оказывает определенное воздействие на физиологическое состояние адгезирован-
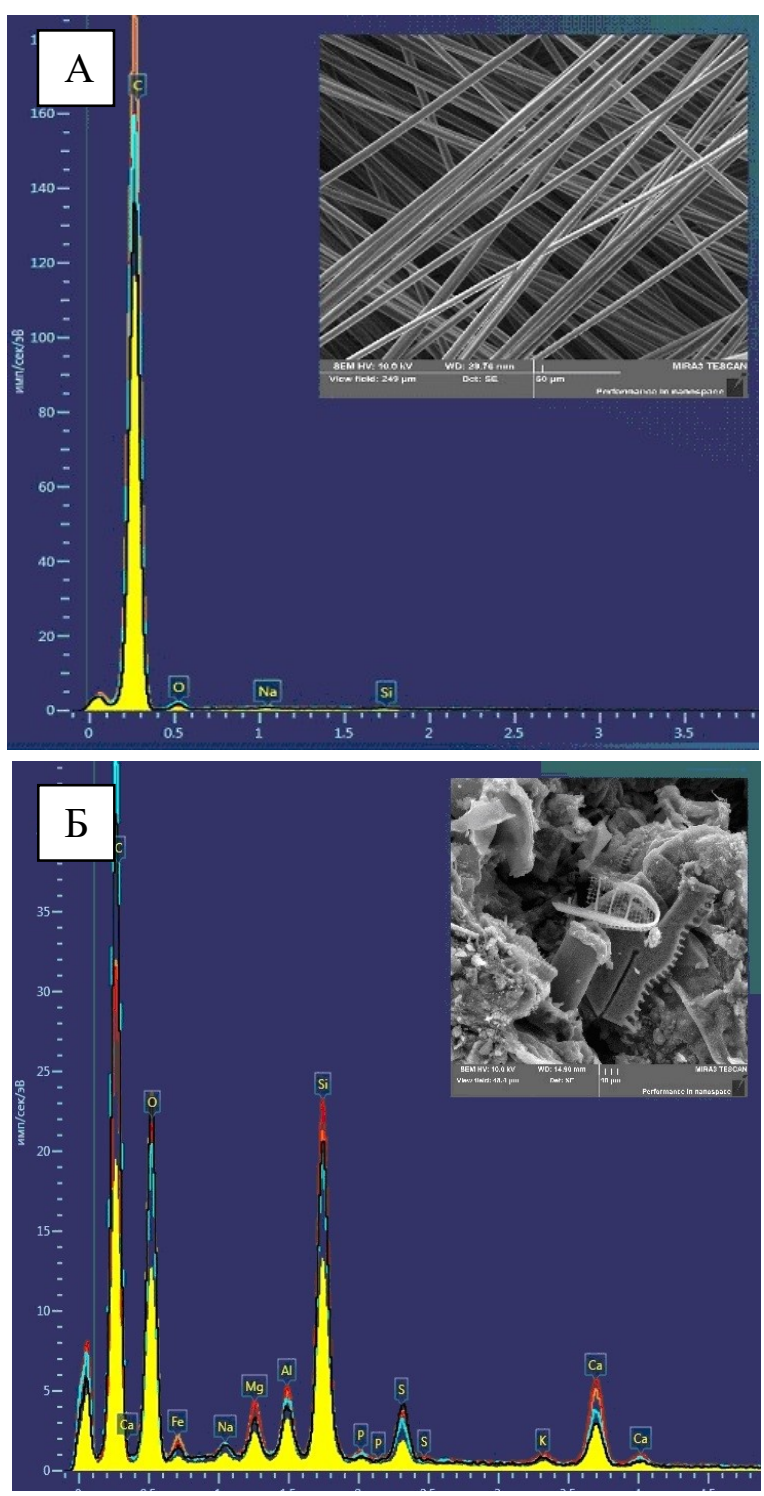

Рис. 2. Элементный состав носителей: карбонизированной ткани Урал ТМ-4 (A) $u$ «Саропель» (Б) ных клеток, следовательно, должен быть учтен при выборе оптимального носителя клеток в гетерогенном биокатализе.

Так, нами было показано [4], что стереоселективность гидролиза рацемических нитрилов карбоновых кислот в гетерогенном процессе зависит от характеристик носителя, на котором адгезированы клетки, катализирующие гидролиз. При часовой конверсии фенилглициннитрила клетками, иммобилизованными на Сибуните, энантиомерный избыток (еe) L-изомера составляет $54 \%$, тогда как при продолжительности реакции 20 ч увеличивается до 96\%. В случае клеток псевдомонад, адгезированных на «Сапропеле», при часовой конверсии еe L-изомера составляет $30 \%$, но при увеличении времени протекания реакции до 20 ч смещается в сторону выхода D-изомера, ее которого к этому времени достигает 78\%.

В качестве контроля реакцию катализировали суспендированными клетками, и в этом случае стереоселективность реакции мало изменялась во времени, a ee L-фенилглицина составлял 50-68\%. Такое изменение энантиомерного избытка одного из образующихся изомеров может быть связано с природой носителя, используемого для адгезии клеток. Была выдвинута гипотеза, по которой изменение $\mathrm{pH}$ в микроокружении адсорбента может влиять на взаимопревращения уже образовавшихся изомеров. Этим может объясняться влияние длительности реакции (контакта реакционной среды с носителем) на энантиомерный избыток одного из стереоизомеров фенилглицина.

\section{Изучение зависимости адгезии микроб- ных клеток на носителе от их концентрации в суспензии}

Клетки после первоначальной адсорбции на носителе адгезируются к нему: сначала процесс обратим, но затем, при участии внеклеточных полисахаридов, бактерии необратимо прикрепляются к поверхности, после чего начинается деление клеток и процесс образования микроколоний, а затем и зрелой биопленки. 
Macса (количество) адсорбированных клеток зависит от их концентрации в суспензии. При этом характер адсорбции, сменяемой впоследствии адгезией, может быть разным. Процесс описывается либо теорией полимолекулярной адсорбции Брунауэра, Эммета, Теллера (БЭТ), что предполагает формирование полислоя клеток на поверхности с высоким адсорбционным потенциалом, либо графики имеют вид изотерм Лэнгмюра.

В последнем случае на кривых наблюдается характерное плато, соответствующее образованию монослойного покрытия из адсорбированных бактериальных клеток. Появление плато на графике свидетельствует о насыщении поверхности носителя клетками. Для различных носителей и бактериальных штаммов были построены графики, отражающие зависимость количества адсорбированных клеток от их концентрации в суспензии. Процесс адсорбции клеток Rh. ruber gt1 на Карбопоне (карбонизированном углеродном нетканом материале) описывался изотермой Лэнгмюра (рис. 3, а), а Rh. erythropolis 11-2 на БАУ (дробленом активном угле) теорией полимолекулярной адсорбции БЭТ (рис. 3, б). Различия в характере процесса в первую очередь связаны со свойствами материала носителя и, кроме того, объясняются способностью клеток к агрегации, которая приводит к образованию полислоя клеток на поверхности носителя.

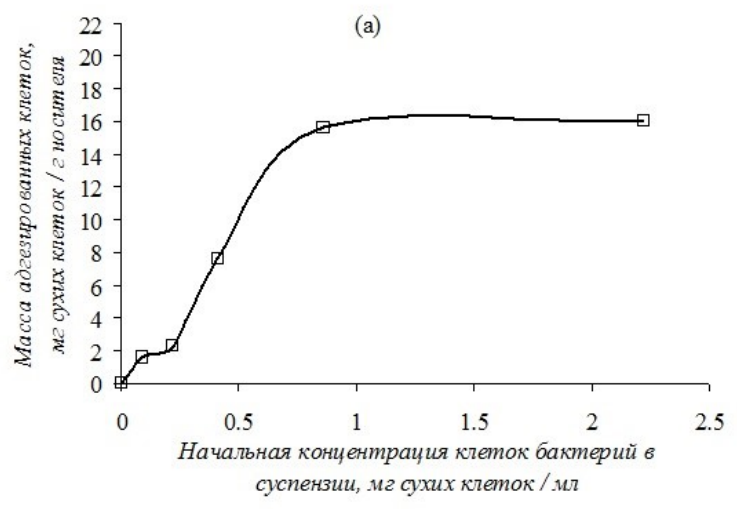

\section{Визуализация адгезированных} бактериальных клеток

Поверхность носителя и процесс адгезии бактериальных клеток могут быть визуализированы с помощью сканирующей электронной микроскопии. Разрешение, которое, в отличие от светового, можно получить в электронном микроскопе, достаточно для изучения характера адгезии микробных клеток, а также их поверхности и поверхности материала носителя. Нами были получены микрофотографии адгезированных бактерий на углеродных носителях (рис. 4).

На микрофотографиях были отмечены как единичные адгезированные клетки, так и их скопления, вызванные агрегацией клеток друг с другом.

\section{Заключение}

Таким образом, процесс адгезии бактериальных клеток на абиотическом материале является результатом взаимодействия поверхности бактериальной клетки с поверхностью носителя и может быть изучен рядом физико-химических и бактериологических методов. Используются методы, позволяющие охарактеризовать такие свойства поверхности материала, как шероховатость, гидрофобность, заряд. Шероховатость может быть определена с помощью интерферометра-профилометра или атомно-силового микроскопа. Гидрофильность и гидрофобность характеризуются краевым углом смачивания, и ее можно оценить по растеканию капли воды на

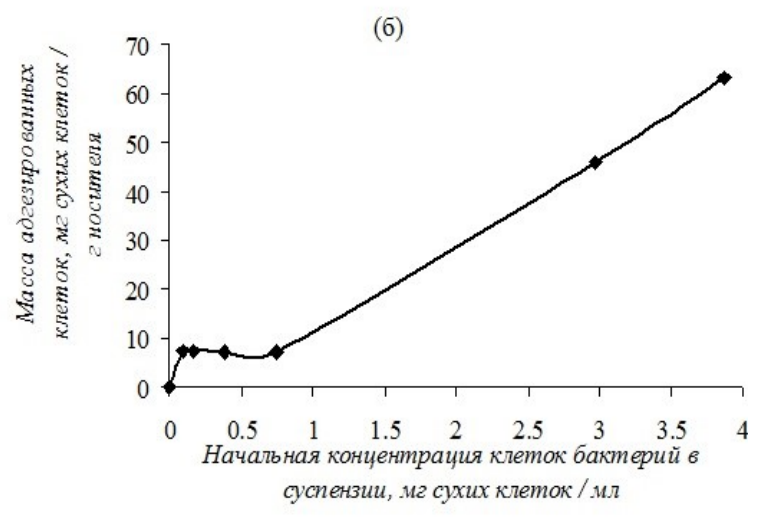

Pис. 3. Зависимость массы адгезированных клеток Rh. ruber gt1 на Карбопоне (а) u Rh. erythropolis 11-2 на БАУ (б) от концентрации клеток бактерий в суспензии 

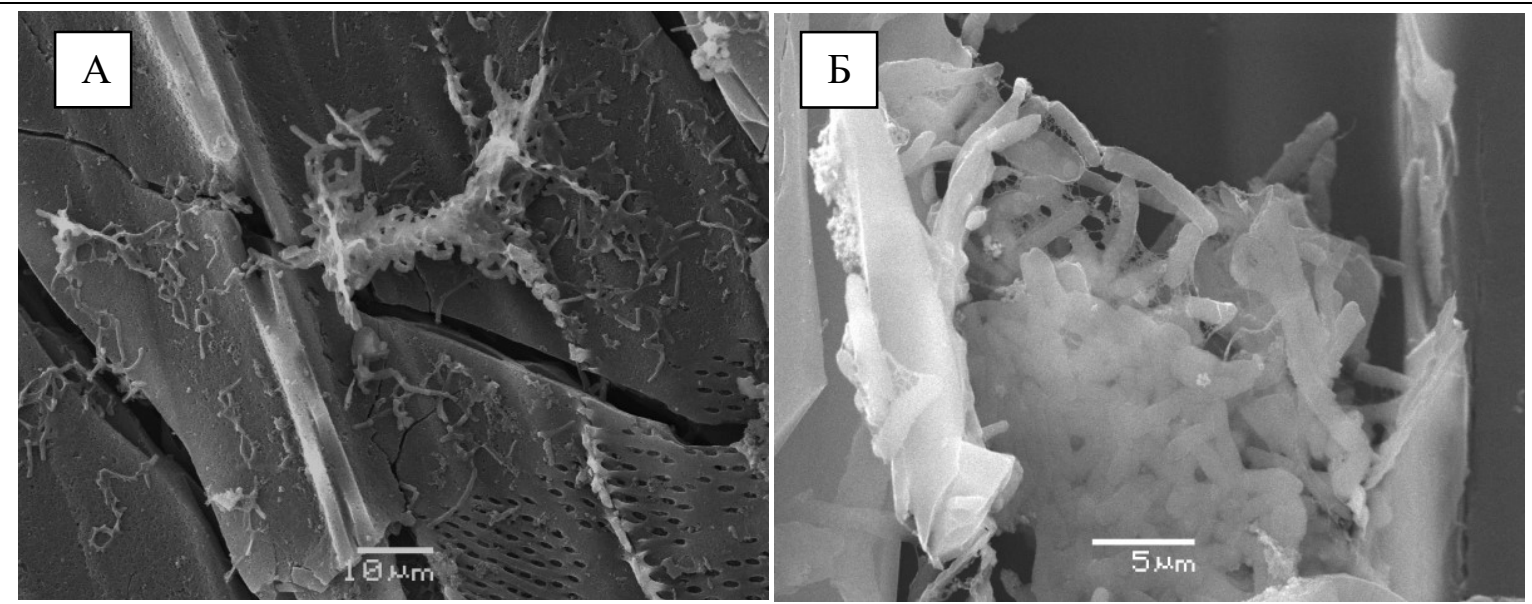

Puc. 4. Микрофотографии клеток R. ruber gt1, адгезированных на БАУ (А) и угле-сырие (Б)

гладкой поверхности тела. У материалов с неровной поверхностью, как в случае углеродных носителей, степень гидрофобности можно определить по адсорбции на их поверхности гидрофобных веществ. Заряд поверхности клеток может быть изучен методом микроэлектрофореза. Количество (масса) клеток, адгезированных на носителе, учитывается по изменению концентрации бактериальных клеток до и после адгезии на носителе. Рентгеновский энергодисперсионный микроанализ дает информацию о составе материала носителя, а сканирующая электронная микроскопия является методом визуализации процесса адгезии клеток.

Адгезия клеток на носителе - один из методов иммобилизации микроорганиз- мов для биокаталитических процессов. Если в биотехнологии используют растущие культуры, то в этом случае адгезия является первым этапом образования биопленки и происходит на стадии инокуляции твердого субстрата. Адгезированные клетки могут быть использованы в качестве биокатализаторов процесса ферментативной трансформации, в составе биофильтров для очистки сточных вод или адсорбента, вносимого в загрязненные среды.

Авторы выражают благодарность заведующему лабораторией физических основ прочности «ИМСС УрО РАН» - филиала ПФИЦ УрО РАН, доктору физико-математических наук, профессору О.Б. Наймарку и ведущему инженеру В.А. Оборину за предоставленную возможность анализа материалов на интерферометре-профилометре New-View 5000.

\section{Библиографический список}

1. Максимов А.Ю., Максимова Ю.Г., Кузнецова М.В., Олонщев В.Ф., Демаков В.А. Иммобилизация на углеродных сорбентах клеток штамма Rhodococcus ruber gt1, обладающего нитрилгидратазной активностью // Прикладная биохимия и микробиология. - Т. 43. - № 2. - 2007. - С. 193-198.

2. Максимова Ю.Г., Коваленко Г.А., Максимов А.Ю., Демаков В.А., Чуенко Т.В., Рудина Н.А. Иммобилизованные нерастущие клетки Rhodococcus ruber как гетерогенные биокатализаторы для процесса гидратации акрилонитрила в акриламид // Катализ в промышленности. - 2008. № 1. - C. 44-50.

3. Максимова Ю.Г., Максимов А.Ю., Демаков В.А., Козлов С.В., Овечкина Г.В., Олонщев В.Ф. Гидролиз акрилонитрила клетками нитрилконвертирующих бактерий, иммобилизованными на волокнистых углеродных адсорбентах // Биотехнология. - 2010. - № 4. - С. 51-58.

4. Максимова Ю.Г., Горбунова А.Н., Демаков В.А. Стереоселективная биотрансформация фенилглициннитрила гетерогенным биокатализатором на основе иммобилизованных бактериальных клеток и ферментного препарата // Доклады академии наук. - 2017. - Т. 474. - № 2. - С. 248-250.

5. Николаев Ю.А., Плакунов В.К. Биопленка - «город микробов» или аналог многоклеточного организма? // Микробиология. - 2007. - Т. 76. - № 2. - С. 149-163.

6. Ножевникова А.Н., Бочкова Е.А., Плакунов В.К. Мультивидовые биопленки в экологии, медицине и биотехнологии // Микробиология. - 2015. - Т. 84. - № 6. - С. 623-644.

7. Сироткин А.С., Шагинурова Г.И., Ипполитов К.Г. Агрегация микроорганизмов: флокулы, биопленки, микробные гранулы. - Казань: изд-во «Фэн» АН РТ, 2007. - 160 с. 
8. Halan B., Buehler K., Schmid A. Biofilms as living catalysts in continuous chemical syntheses // Trends Biotechnol. - 2012. - Vol. 30(9). - P. 453-465.

9. Gross R., Hauer B., Otto K., Schmid A. Microbial biofilms: new catalysts for maximizing productivity of long-term biotransformations // Biotechnol Bioeng. - 2007. - Vol. 98. - № 6. - P. 1123-1134.

10. Kovalenko G.A., Kuznetsova E.V., Mogilnykh Yu.I., Andreeva I.S., Kuvshinov D.G., Rudina N.A. Catalytic filamentous carbons for immobilization of biologically active substances and non-growing bacterial cells // Carbon. - 2001. - Vol. 39. - P. 1033-1043.

11. Rosche B., Li X.Z., Hauer B., Schmid A., Buehler K. Microbial biofilms: a concept for industrial catalysis? // Trends Biotechnol. - 2009. - Vol. 27. - № 11. - P. 636-643.

12. Rosenberg M., Gutnik D., Rosenberg E. Adherence of bacteria to hydrocarbons: A simple method for measuring cell surface hydrophobicity // FEMS Microbiol. Lett. - 1980. - Vol. 9. - P. 29-33.

\title{
ADHESION OF BACTERIAL CELLS ON CARBON SUPPORTS: CHARACTERISTICS OF PROCESS AND APPLICATION IN BIOTECHNOLOGY
}

\author{
Yu.G. Maksimova, A.Yu. Maksimov, V.A. Demakov \\ Institute of Ecology and Genetics of Microorganisms UB RAS
}

The article provides a brief review of methods for studying the process of adhesion of bacterial cells on insoluble abiotic carriers (carbon materials). Determination of the hydrophobicity of microbial cells and the carrier, dispersion, surface roughness of the carrier allows to identify the main patterns of bacterial adhesion on carbon adsorbents. It is shown that the adhered biomass on a hydrophobic carrier is the greater, the higher the hydrophobicity of the cell surface. Correlation analysis showed no reliable relationship between surface roughness, hydrophobicity and dispersion of carriers on the one hand, and the mass of adhered cells on the other hand when considering these characteristics separately, which indicates the need for a comprehensive approach to the assessment of the carrier for immobilizing microbial cells. The mass (amount) of adsorbed cells depends on their concentration in the suspension. The nature of adsorption, subsequently replaced by adhesion, can be described either by the theory of polymolecular adsorption of Brunauer, Emmett, Teller, which implies the formation of a cells polylayer on the surface, or in the case of carrier saturation with cells, the graphs look like Langmuir isotherms. The elemental composition of the carrier has a certain effect on the physiological state of the adhered cells, therefore, it must be taken into account when choosing the optimal carrier of cells in heterogeneous biocatalysis. Scanning electron microscopy allows visualization of adherent cells. Adherent cells of nitrile-hydrolyzing bacteria can be used as biocatalysts for the process of enzymatic transformation of nitriles and amides or in the process of treatment of environment from these toxic substances.

Keywords: bacterial adhesion, biofilms, carbon materials, immobilization of microbial cells, hydrophobicity, profilometry, scanning electron microscopy, X-ray energy dispersive microanalysis.

\section{Сведения об авторах}

Максимова Юлия Геннадьевна, доктор биологических наук, ведущий научный сотрудник лаборатории молекулярной микробиологии и биотехнологии, Институт экологии и генетики микроорганизмов УрО РАН - филиал Пермского федерального исследовательского центра УрО РАН (ИЭГМ УрО РАН), 614081, г. Пермь, ул. Голева, 13; e-mail: yul_max@mail.ru

Максимов Александр Юрьевич, кандидат биологических наук, старший научный сотрудник лаборатории молекулярной микробиологии и биотехнологии, ИЭГМ УpO PAH; e-mail: alm@iegm.ru Демаков Виталий Алексеевич, доктор медицинских наук, профессор, член-корреспондент РАН, заведующий лабораторией молекулярной микробиологии и биотехнологии, директор ИЭГМ УрО PAH; e-mail: demakov@iegm.ru 